\title{
HUBUNGAN KEPEMIMPINAN SITUASIONAL KEPALA SEKOLAH DAN KEPERCAYAAN PADA ORGANISASI DENGAN KEPUASAN KERJA
}

\author{
Sopyan $^{1}$, Bibin Rubini ${ }^{2}$, Griet Helena Laihad ${ }^{2}$. \\ ${ }^{1}$ Kepala Sekolah SDN Pasirkaliki I Kecamatan Rawamerta, Kabupaten Karawang \\ ${ }^{2}$ Program Pascasarjana Universitas Pakuan \\ Email: pasca@unpak.ac.id
}

\begin{abstract}
Teacher job satisfaction is an emotional feeling that is pleasant or not pleasing to a job according to the results of a person's assessment and experience. The achievement of teacher job satisfaction is one of the phenomena of the successful implementation of an organization's work program. Correlational research consists of two independent variables namely situational leadership of the principal and trust (trust) and the dependent variable is teacher job satisfaction. This research was conducted in 2017 in the State Elementary School in Rawamerta Sub-District, Karawang Regency, which consisted of 26 schools using the survey method. The number of samples of 150 respondents with sampling techniques using proportional random sampling technique. Data analysis techniques used statistical correlation techniques and simple linear regression and multiple correlations and regression. Hypothesis testing is done at the 0.05 level of significance. The results showed that: 1) There is a very significant positive relationship between principals' situational leadership $(X 1)$ and teacher job satisfaction $(Y)$ with ryl $=0.4824$ with a regression equation $\hat{Y}=71.66+0.3464 X 1,2)$ There is a significant positive relationship between trust $(X 2)$ and teacher job satisfaction $(Y)$ with $r x 2 y=r y 2=0.7196$ with the regression equation $\hat{Y}=48.22$ $+0.4576 \mathrm{X} 2$ and 3) there is a significant positive relationship between Principal situational leadership and trust with teacher job satisfaction with rxlx2y $=0.7450$ with a regression equation $\hat{Y}=40.76+0.152 X 1+0.399 X 2$.
\end{abstract}

Keywords: situational leadership, trust, job satisfaction.

\begin{abstract}
ABSTRAK
Kepuasan kerja guru adalah perasaan emosi yang menyenangkan atau tidak meyenangkan terhadap suatu pekerjaan menurut hasil penilaian dan pengalaman seseorang. Ketercapaian kepuasan kerja guru merupakan salah satu fenomena keberhasilan pelaksanaan program kerja organisasi. Penelitian korelasional yang terdiri atas dua variabel bebas yaitu kepemimpinan situasional kepala sekolah dan kepercayaan (trust) dan variabel terikat yaitu kepuasan kerja guru. Penelitian ini dilaksanakan pada tahun 2017 di lingkungan SD Negeri di Kecamatan Rawamerta Kabupaten Karawang, yang terdiri dari 26 sekolah dengan menggunakan metode survei. Jumlah sampel sebanyak 150 responden dengan teknik pengambilan sampel menggunakan teknik proportional random sampling. Teknik analisis data menggunakan teknik statistik korelasi dan regresi linier sederhana serta korelasi dan regresi ganda. Pengujian hipotesis dilakukan pada taraf signifikansi 0,05 . Hasil penelitian menunjukan bahwa: 1) Terdapat hubungan positif yang sangat signifikan antara kepemimpinan situasional kepala sekolah $\left(\mathrm{X}_{1}\right)$ dengan kepuasan kerja guru $(\mathrm{Y})$ dengan $\mathrm{r}_{\mathrm{y} 1}=0,4824$ dengan persamaan regresi $\left.\hat{\mathrm{Y}}=71,66+0,3464 \mathrm{X}_{1}, 2\right)$ Terdapat hubungan positif yang signifikan antara
\end{abstract}


kepercayaan (Trust) $\left(\mathrm{X}_{2}\right)$ dengan kepuasan kerja guru $(\mathrm{Y})$ dengan $\mathrm{r}_{\mathrm{x} 2 \mathrm{y}}=\mathrm{r}_{\mathrm{y} 2}=0,7196$ dengan persamaan regresi $\hat{\mathrm{Y}}=48,22+0,4576 \mathrm{X}_{2}$ dan 3) terdapat hubungan positif yang signifikan antara kepemimpinan situasional kepala sekolah dan kepercayaan (Trust) dengan kepuasan kerja guru dengan $r_{x 1 \times 2 y}=0,7450$ dengan persamaan regresi $\hat{Y}=40,76+0,152 X_{1}+0,399$ $\mathrm{X}_{2}$.

Kata Kunci: kepemimpinan situasional, kepercayaan (trust) dan kepuasan kerja.

\section{PENDAHULUAN}

Pendidikan adalah proses pengubahan sikap dan tata laku seseorang atau kelompok orang dalam usaha mendewasakan manusia melalui upaya pengajaran dan pelatihan. Peningkatan mutu lulusan (output) di setiap jenjang pendidikan khususnya pendidikan dasar dan menengah menjadi suatu pekerjaan yang sangat berat harus dilakukan oleh pemerintah. Berbagai upaya telah dilakukan oleh pemerintah untuk meningkatkan mutu pendidikan, antara lain melalui berbagai pelatihan dan peningkatan kompetensi guru, pengadaan buku dan alat pelajaran, perbaikan sarana dan prasarana pendidikan, termasuk peningkatan mutu guru melalui sertifikasi guru. Akan tetapi, berbagai indikator mutu pendidikan yang diharapkan belum menunjukkan peningkatan yang berarti. Sebagian sekolah menunjukkan hasil yang cukup menggembirakan, namun sebagian besar lainnya masih dalam kondisi yang memprihatinkan. Dari berbagai aspek yang mampu berperan dalam upaya peningkatkan mutu pendidikan. Guru merupakan kunci keberhasilan pendidikan, sebab inti dari kegiatan pendidikan adalah belajar mengajar yang memerlukan peran serta guru di dalamnya.

Guru adalah suatu sebutan bagi jabatan, posisi, dan profesi bagi seseorang yang mengabdikan dirinya dalam bidang pendidikan melalui interaksi edukatif secara terpola, formal, dan sistematis. Guru merupakan pendidik professional dengan tugas utama mendidik, mengajar, membimbing, mengarahkan, melatih, menilai dan mengevaluasi peserta didik baik jalur pendidikan formal maupun non formal, pada jenjang pendidikan dasar dan pendidikan menengah. Guru profesional akan tercermin dalam penampilan pelaksanaan tugas-tugas yang ditandai dengan keahlian baik dalam materi maupun metode pembelajaran. Keahlian yang dimiliki oleh guru profesional adalah keahlian yang diperoleh melalui suatu proses pendidikan dan pelatihan yang diprogramkan secara khusus. Keahlian tersebut mendapat pengakuan formal yang dinyatakan dalam bentuk sertifikasi, akreditasi, dan lisensi dari pihak yang berwenang sebagai guru profesional baik pemerintah maupun organisasi profesi itu sendiri.

\section{Kepuasan Kerja Guru}

Schermerhorn (2010: 72) memberikan pengertian "Job satisfactions is the degree to which an individual feels positively or negatively about his job kepuasan kerja adalah tingkat di mana individu merasakan positif atau negatif tentang suatu pekerjaan". Menurut Jenifer dan Jones (2012: 75) "Job satisfaction is the collection of feelings and beliefs that people have about their current jobs. Kepuasan kerja adalah kumpulan perasaan dan kepercayaan yang dimiliki orang tentang pekerjaan mereka saat ini."

Noe et al. (2012: 458) mengungkapkan "job satisfaction define as a pleasurable feeling that results from the perception that one's job fulfills or allow for the fulfillment of one's important job values". Kepuasan kerja didefinisikan sebagai perasaan menyenangkan yang dihasilkan dari persepsi bahwa pekerjaan seseorang memenuhi atau memungkinkan pemenuhan nilai pekerjaan penting seseorang. Umar (2008: 213) menyatakan bahwa "kepuasan kerja adalah perasaan dan penilaian seorang atas pekerjaannya, khususnya 
mengenai kondisi kerjanya, dalam hubungannya dengan apakah pekerjaannya mampu memenuhi harapan, kebutuhan, dan keinginannya".

Berdasarkan kajian teori tentang kepuasan kerja di atas, maka dapat disimpulkan bahwa kepuasan kerja adalah perasaan emosi yang menyenangkan atau tidak meyenangkan terhadap suatu pekerjaan menurut hasil penilaian dan pengalaman seseorang.

\section{Kepemimpinan Situasional Kepala Sekolah}

Menurut Hersey-Blanchard (dalam Thoha: 2003: 316), kepemimpinan situasional (kontingensi) adalah kepemimpinan yang berfokus kepada kesiapan bawahan yang memiliki karakteristik, dan kematangan yang berbeda-beda. Para pemimpin harus menilai secara benar atau secara intuitif mengetahui tingkat kematangan pengikut-pengikutnya dan kemudian menggunakan gaya kepemimpinan yang sesuai dengan tingkat tersebut. Gaya kepemimpinan situasional menurut Hersey dan Blanchard dalam Thoha (2003:317) Dalam hubungannya dengan prilaku kepemimpinan ini, ada dua hal yang biasanya dilakukan terhadap bawahannya atau pengikutnya.

Sedarmayanti (2011: 22) menyatakan bahwa kepemimpinan situasional adalah kepemimpinan yang didasarkan atas hubungan saling mempengaruhi antara; 1) Tingkat bimbingan dan arahan yang diberikan pemimpin (perilaku tugas) 2) Tingkat dukungan sosio emosional yang disajikan pemimpin (perilaku hubungan) 3) Tingkat kesiapan yang diperlihatkan bawahan dalam melaksanakan tugas, fungsi/tujuan tertentu (kematangan bawahan).

Berdasarkan kajian teori tentang kepemimpinan situasional di atas, maka dapat disimpulkan bahwa kepemimpinan situasional adalah efektivitas pemimpin dalam mempengaruhi bawahan tergantung kepada kesiapan, situasi karakteristik, kematangan para pengikutnya dalam pencapaian tujuan.

\section{Kepercayaan (trust)}

Menurut Peppers and Rogers (2004: 43), kepercayaan (trust) adalah keyakinan satu pihak pada reliabilitas, abilitas, dan integritas pihak lain dalam relationship dan keyakinan bahwa tindakannya merupakan kepentingan yang paling baik dan akan menghasilkan hasil positif bagi pihak yang dipercaya. Kepercayaan merupakan hal penting bagi kesuksesan relationship. Suzanne (2012: 35) mendefinisikan "trust is a multifaceted concept that captures one's faith or belief in the integrityor reliability of another person or thing. simply put, trust means confidence" kepercayaan adalah sebuah konsep multifaset (beraneka) yang menangkap kepercayaan atau keyakinan seseorang pada integritas atau kehandalan dari orang lain atau suatu hal, secara sederhana konsep kepercayaan mengandung arti keyakinan.

George (2012: 76) "Trustis an expression of confidence in another person or group of people that you will not be put at risk, harmed, or in jured by their actions". Kepercayaan adalah ungkapan rasa percaya diri pada orang atau kelompok orang lain bahwa anda tidak akan berisiko, dirugikan, atau diikat oleh tindakan mereka. Menurut Robbins (2011: 97) trust adalah ekspektasi atau pengharapan positif dari seseorang tanpa melalui kata-kata, tindakan, dan kebijakan serta oportunistik.

Dari definisi trust sebagaimana yang dijelaskan di atas dapat disimpulkan bahwa yang dimaksud dengan kepercayaan (trust) adalah Keyakinan seseorang atau sekelompok orang kepada pihak lain dalam hubungan postif karena kejujuran dan kehandalannya merasa tidak akan berisiko atau merugikan. 


\section{METODE PENELITIAN}

Penelitian ini menggunakan pendekatan kuantitatif dengan asumsi bahwa penelitian dimulai dari teori yang ada dan dimengerti untuk selanjutnya dilakukan verifikasi secara empirik. Populasi dalam penelitian ini adalah guru kelas Sekolah Dasar yang bersatatus PNS yang sudah bersertifikat pendidik di Kecamatan Rawamerta Kabupaten Karawang sebanyak 150 orang. Teknik sampling yang digunakan oleh peneliti dalam pengambilan sampel pada penelitian ini adalah dengan menggunakan teknik simple random sampling.

\section{HASIL PENELITIAN}

\section{Pengujian Persyaratan Analisis}

\section{Uji Normalitas}

Hasil analisa perhitungan normalitas galat taksiran didapatkan nilai $\mathrm{L}_{\mathrm{o}}$ maks $=0,0665$ sementara itu $\mathrm{L}_{\text {tabel }}=0,08448$. Persyaratan normal adalah $\mathrm{L}_{\mathrm{o}}$ maks $<\mathrm{L}_{\text {tabel }}$ menunjukan bahwa galat baku taksiran data kepuasan kerja guru atas kepemimpinan situasional kepala sekolah berasal dari data yang berdistribusi normal.

Hasil analisa perhitungan normalitas galat taksiran didapatkan nilai $\mathrm{L}_{\mathrm{o}}$ maks $=0,0646$ sementara itu $\mathrm{L}_{\text {tabel }}=0,0845$. Persyaratan normal adalah $\mathrm{L}_{\mathrm{o} \text { maks }}<\mathrm{L}_{\text {tabel }}$ menunjukan bahwa galat baku taksiran data kepuasan kerja guru atas kepercayaan (trust) berasal dari data yang berdistribusi normal.

\section{Uji Homogenitas}

Uji homogenitas data kepuasan kerja guru atas kepemimpinan situasional kepala sekolah diuji dengan menggunakan Uji Barlett. Berdasarkan uji tersebut diperoleh nilai $\boldsymbol{\aleph}^{2}$ hitung $=58,873$ sedangkan $\boldsymbol{\aleph}^{2}$ tabel $=97,350$. Persyaratan homogen adalah $\boldsymbol{\aleph}^{2}$ hitung $\left\langle\boldsymbol{\aleph}^{2}\right.$ tabel, kelompok data kepuasan kerja guru atas kepemimpinan situasional kepala sekolah berasal dari data yang homogen.

Uji homogenitas data kepuasan kerja guru atas kepercayaan (trust) diuji dengan menggunakan Uji Barlett. Berdasarkan uji tersebut diperoleh nilai $\boldsymbol{\aleph}^{2}$ hitung $=68,755$ sedangkan $\boldsymbol{\aleph}^{2}$ tabel $=93,945$. Persyaratan homogen adalah $\boldsymbol{\aleph}^{2}$ hitung $<\boldsymbol{\aleph}^{2}$ tabel, kelompok data kepuasan kerja guru atas kepercayaan (trust)berasal dari data yang homogen.

\section{Pengujian Hipotesis}

\section{Hubungan Kepemimpinan Situasional Kepala Sekolah $\left(X_{1}\right)$ dengan Kepuasan} Kerja Guru(Y)

Analisis linier sederhana antara kepemimpinan situasional kepala sekolah dengan kepuasan kerja guru memiliki persamaan regresi $\hat{Y}=71,666+0,3464 \mathrm{X}_{1}$ dengan arah koefisien regresi sebesar 0,4576 dan konstanta sebesar 71,666. Pengujian mengenai seberapa besar kebenaran hasil regresi tersebut, yang juga dimaksudkan untuk menguji hipotesis tentang adanya hubungan positif antara kepemimpinan situasional kepala sekolah $\left(\mathrm{X}_{1}\right)$ dengan kepuasan kerja guru (Y), maka untuk keperluan itu diperlukan uji signifikansi dan linier terhadap persamaan regresi dengan menggunakan uji $\mathrm{F}$.

Perhitungan Analisis korelasi sederhana menghasilkan koefisien korelasi $r$ sebesar 0,48241 dan koefisien determinasi $\left(\mathrm{r}^{2}\right)$ sebesar 23,2719\%. Hasil pengujian keberartian koefisien korelasi diperoleh $t_{\text {hitung }}$ sebesar 5,723 yang lebih besar dari $t_{\text {tabel }}$ sebesar 1,658. Berdasarkan data tersebut di atas maka hasil uji hipotesis kepemimpinan situasional kepala sekolah $\left(\mathrm{X}_{1}\right)$, dapat disimpulkan bahwa $\mathrm{H}_{\mathrm{o}}$ ditolak, sedangkan $\mathrm{H}_{1}$ yang menyatakan terdapat hubungan positif antara $\mathrm{X}_{1}$ (kepemimpinan situasional kepala sekolah) dengan $\mathrm{Y}$ (kepuasan kerja guru) diterima. 


\section{Hubungan Kepercayaan (trust) ( $\mathrm{X}_{2}$ ) dengan Kepuasan Kerja Guru (Y)}

Analisis linier sederhana antara kepercayaan (trust) dengan kepuasan kerja guru memiliki persamaan regresi $\hat{\mathrm{Y}}=48,22+0,4576 \mathrm{X}_{2}$ dengan arah koefisien regresi sebesar 0,4576 dan konstanta sebesar 48,22. Pengujian mengenai seberapa besar kebenaran hasil regresi tersebut, yang juga dimaksudkan untuk menguji hipotesis tentang adanya hubungan positif antara kepercayaan (trust) $\left(\mathrm{X}_{2}\right)$ dengan kepuasan kerja guru (Y), maka untuk keperluan itu diperlukan uji signifikansi dan linier terhadap persamaan regresi dengan menggunakan uji $\mathrm{F}$.

Perhitungan Analisis korelasi sederhana menghasilkan koefisien korelasi $\mathrm{r}$ sebesar 0,71965 dan koefisien determinasi $\left(\mathrm{r}^{2}\right)$ sebesar $51,7897 \%$. Hasil pengujian keberartian koefisien korelasi diperoleh $t_{\text {hitung }}$ sebesar 10,77 yang lebih besar dari $t_{\text {tabel }}$ sebesar 1,658. Berdasarkan data tersebut di atas maka hasil uji hipotesis kepercayaan $\left(\mathrm{X}_{2}\right)$, dapat disimpulkan bahwa $\mathrm{H}_{\mathrm{o}}$ ditolak, sedangkan $\mathrm{H}_{1}$ yang menyatakan terdapat hubungan positif antara $\mathrm{X}_{2}$ (kepercayaan) dengan $\mathrm{Y}$ (kepuasan kerja guru ) diterima.

\section{Hubungan Kepemimpinan Situasional Kepala Sekolah $\left(\mathrm{X}_{1}\right)$ dan Kepercayaan(trust) $\left(\mathbf{X}_{2}\right)$ dengan Kepuasan Kerja Guru (Y)}

Analisis regresi linier ganda antara kepemimpinan situasional kepala sekolah dan kepercayaan (trust) secara besama-sama dengan Kepuasan Kerja Guru ditampilkan dalam bentuk persamaan regresi sebagai berikut: $\hat{Y}=40,76+0,152 X_{1}+0,399 X_{2}$, dengan arah koefisien regresi $a_{1}$ sebesar 0,152, a sebesar 0,399 dan konstanta $a_{0}$ sebesar 40,76. Untuk menguji hipotesis yang menyatakan bahwa terdapat hubungan positif antara kepemimpinan situasional kepala sekolah $\left(\mathrm{X}_{1}\right)$ dan kepercayaan (trust) $\left(\mathrm{X}_{2}\right)$ secara bersama-sama dengan kepuasan kerja guru (Y), diperlukan uji signifikansi dan linier terhadap persamaan regresi dengan menggunakan uji $\mathrm{F}$.

Hasil perhitungan uji keberartian persamaan regresi linier ganda diperoleh $F_{\text {hitung }}=$ 78,842 yang lebih besar dari $\mathrm{F}_{\text {tabel }}=3,090$. Berdasarkan data ini dapat diambil kesimpulan bahwa $\mathrm{H}_{0}$ ditolak, artinya $\mathrm{H}_{1}$ yang menyatakan hubungan positif antara $\mathrm{X}_{1}$ (Kepemimpinan situasional kepala sekolah) dan $\mathrm{X}_{2}$ (Kepercayaan (trust) ) secara bersama-sama dengan $\mathrm{Y}$ ( Kepuasan kerja guru ) diterima.

\section{Uji korelasi Parsial}

Koefisien korelasi antara kepemimpinan situasional kepala sekolah dengan kepuasan kerja guru dikontrol oleh variabel kepercayaan (trust) sekolah memiliki nilai $\mathrm{r}_{\mathrm{y} 12}$ sebesar 0,277. Pengujian tingkat signifikansi dari koefisien korelasi parsial yang dikontrol oleh variabel $\mathrm{X}_{2}$ dilakukan dengan uji $\mathrm{t}$. Hasil perhitungan diperoleh $\mathrm{t}_{\text {hitung }}=2,977$ yang lebih besar dari pada $t_{\text {tabel }}=1,980$, dengan demikian hubungan antara kepemimpinan situasional kepala sekolah $\left(\mathrm{X}_{1}\right)$ dengan kepuasan kerja guru $(\mathrm{Y})$ tetap signifikan meskipun dikontrol oleh variabel kepercayaan (trust) atau dengan kata lain variabel kepercayaan (trust) $\left(\mathrm{X}_{2}\right)$ tidak berhubungan secara signifikan dengan kepemimpinan situasional kepala sekolah $\left(\mathrm{X}_{1}\right)$ dalam hubungannya dengan kepuasan kerja guru (Y).

Koefisien korelasi antara kepercayaan (trust) dengan kepuasan kerja guru dikontrol oleh variabel kepemimpinan situasional kepala sekolah memiliki nilai $\mathrm{r}_{\mathrm{y} 21}$ sebesar 0,648. Pengujian tingkat signifikansi dari koefisien korelasi parsial yang dikontrol oleh variabel $\mathrm{X}_{1}$ dilakukan dengan uji t. Hasil perhitungan diperoleh $t_{\text {hitung }}=8,797$ yang lebih besar daripada $\mathrm{t}_{\text {tabel }}=1,980$, dengan demikian hubungan antara kepercayaan (trust) $\left(\mathrm{X}_{2}\right)$ dengan kepuasan kerja guru (Y) tetap signifikan meskipun dikontrol oleh variabel kepemimpinan situasional kepala sekolah atau dengan kata lain variabel kepemimpinan situasional kepala sekolah $\left(\mathrm{X}_{1}\right)$ tidak berhubungan secara signifikan dengan kepercayaan $\left(\mathrm{X}_{2}\right)$ dalam hubungannya dengan kepuasan kerja guru (Y). 


\section{PEMBAHASAN}

\section{Hubungan antara Kepemimpinan Situasional Kepala Sekolah dengan Kepuasan Kerja Guru}

Hasil perhitungan analisis linier sederhana bentuk hubungan kepemimpinan situasional kepala sekolah dengan kepuasan kerja guru memiliki persamaan regresi $\hat{Y}=71,66+0,3464$ $\mathrm{X}_{1}$ dengan arah koefisien regresi sebesar 0,4576 dan konstanta sebesar 71,666. Hasil uji

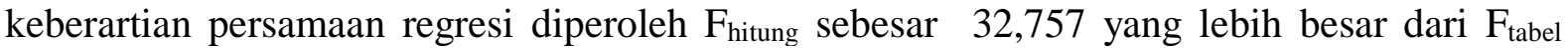
sebesar 3,94. Demikian pula dari hasil uji linieritas diperoleh $F_{\text {hitung }}$ sebesar 1,567 yang lebih kecil dari $\mathrm{F}_{\text {tabel }}$ sebesar 1,65.Perhitungan Analisis korelasi sederhana menghasilkan koefisien korelasi $r$ sebesar 0,48241 dan koefisien determinasi $\left(r^{2}\right)$ sebesar $23,2719 \%$. Hasil pengujian keberartian koefisien korelasi diperoleh $t_{\text {hitung }}$ sebesar 5,723yang lebih besar dari $t_{\text {tabel }}$ sebesar 1,658. Berdasarkan data tersebut di atas maka hasil uji hipotesis kepemimpinan situasional kepala sekolah $\left(\mathrm{X}_{1}\right)$ dapat disimpulkan bahwa $\mathrm{H}_{\mathrm{o}}$ ditolak. Artinya hipotesis $\mathrm{H}_{1}$ yang menyatakan terdapat hubungan positif antara $\mathrm{X}_{1}$ (Kepemimpinan situasional kepala sekolah) dengan Y ( kepuasan kerja guru) diterima.

Hasil penelitian sebelumnya yang dilakukan Agustia (2009: 30) Universitas Airlangga, dalam penelitiannya yang berjudul Pengaruh Gaya Kepemimpinan Situasional, Motivasi Kerja Locus of Control dengan Kepuasan Kerja. Hasil studi membuktikan bahwa terdapat hubungan positif dan signifikanantara gaya kepemimpinan situasional dengan kepuasan kerja. Hal ini ditunjukkan oleh nilai signifikansi $=0.003$ lebih kecil dari level of significant $=$ $0.05(5 \%)$. Hal ini berarti semakin tinggi tingkat kepemimpinan situasional kepala sekolah maka akan semakin tinggi pula kepuasan kerja guru.

Dengan demikian temuan fakta dan data dalam analisis penelitian ini semakin mendukung temuan-temuan terdahulu mengenai adanya hubungan positif antara kepemimpinan situasional kepala sekolah dengan kepuasan kerja guru.

\section{Hubungan antara Kepercayaan (trust) dengan Kepuasan Kerja Guru}

Hasil perhitungan analisis linier sederhana bentuk hubungan kepercayaan (trust) dengan kepuasan kerja guru memiliki persamaan regresi $\hat{Y}=48,22+0,4576 \mathrm{X}_{2}$ dengan arah koefisien regresi sebesar 0,4576 dan konstanta sebesar 48,22. Hasil uji keberartian persamaan

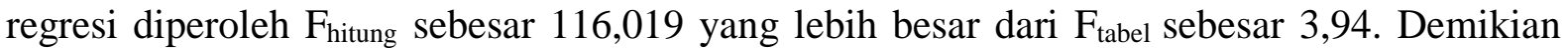

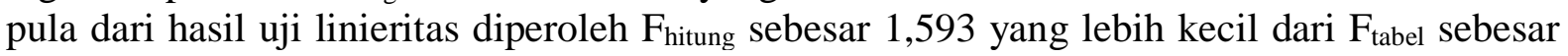
1,65. Perhitungan Analisis korelasi sederhana menghasilkan koefisien korelasi $\mathrm{r}$ sebesar 0,71965 dan koefisien determinasi $\left(\mathrm{r}^{2}\right)$ sebesar $51,7897 \%$. Hasil pengujian keberartian koefisien korelasi diperoleh $t_{\text {hitung }}$ sebesar 10,77yang lebih besar dari $t_{\text {tabel }}$ sebesar 1,658. Berdasarkan data tersebut di atas maka hasil uji hipotesis kepemimpinan situasional kepala sekolah $\left(\mathrm{X}_{1}\right)$ dapat disimpulkan bahwa $\mathrm{H}_{\mathrm{o}}$ ditolak. Artinya hipotesis $\mathrm{H}_{1}$ yang menyatakan terdapat hubungan positif antara $\mathrm{X}_{2}$ (kepercayaan (trust)) dengan $\mathrm{Y}$ (kepuasan kerja guru) diterima.

Hasil penelitian sebelumnya pada Jurnal Kependidikan, Volume 46, Nomor 1, Mei 2016, kepercayaan (trust) berpengaruh positif dan signifikan terhadap kepuasan kerja tenaga kependidikan, Variabel Trust, memiliki kontribusi atau pengaruh yang kuat yaitu sebesar $82 \%$ terhadap varians variabel Kepuasan Kerja.. Sisanya $18 \%$ dijelaskan oleh faktor selain variabel Trust.

Hal ini berarti semakin tinggi tingkat kepercayaan (trust) maka akan semakin tinggi pula kepuasan kerja guru. Dengan demikian temuan fakta dan data dalam analisis penelitian ini semakin mendukung temuan-temuan terdahulu mengenai adanya hubungan positif antara kepercayaan (trust) dengan kepuasan kerja guru. 


\section{Hubungan antara Kepemimpinan Situasional Kepala Sekolah dan Kepercayaan (trust) Secara Bersama-Sama dengan Kepuasan Kerja Guru}

Analisis regresi linier ganda antara kepemimpinan situasional kepala sekolah dan kepercayaan (trust) secara besama-sama dengan kepuasan kerja guru ditampilkan dalam bentuk persamaan regresi sebagai berikut: $\hat{Y}=40,76+0,152 \mathrm{X} 1+0,399$ X2, dengan arah koefisien regresi a sebesar 0,152, a sebesar 0,399 dan konstanta a sebesar 40,76. Hasil perhitungan uji keberartian persamaan regresi linier ganda diperoleh $F_{\text {hitung }}=78,842$ yang lebih besar dari $\mathrm{F}_{\text {tabel }}=3,090$.

Hal tersebut di atas sesuai dengan teori kepemimpinan situasional kepala sekolah sebagaimana dijelaskan oleh Hersey-Blanchard di atas. Kepemimpinan berfokus kepada bagaimana kesiapan bawahan yang memiliki karakteristik, dan kematangan yang berbedabeda. Hasil penelitian relevan terdahulu yang dilakukan berdasarkan hasil penelitian pada Jurnal Kependidikan, Volume 46, Nomor 1, Mei 2016, kepercayaan (trust) berpengaruh positif dan signifikan terhadap kepuasan kerja tenaga kependidikan, Variabel Trust, memiliki kontribusi atau pengaruh yang kuat terhadap kepuasan kerja guru seperti yang telah disampaikan sebelumnya, maka dapat disimpulkan bahwa terdapat pengaruh positif antara kepemimpinan situasional kepala sekolah dan kepercayaan (trust) secara bersama-sama terhadap kepuasan kerja guru. Dengan demikan apabila kepemimpinan situasional kepala sekolah tinggi dan memiliki kepercayaan (trust) yang tinggi pula, maka secara bersama-sama akan sanggup meningkatkan kepuasan kerja guru di sekolah tersebut secara signifikan dan berkesinambungan.

Selain itu untuk melihat seberapa besar kekuatan hubungan antara variabel bebas dan variabel terikat serta untuk mendapatkan solusi optimal dari penelitian ini dapat di lihat pada gambar konstelasi penelitian dan statistik berdasarkan teori pengenalan ilmiah untuk riset operasi di bidang Manajemen Pendidikan atau dikenal dengan SITOREM (Hardhienata: 2017) seperti ditunjukkan pada gambar berikut:

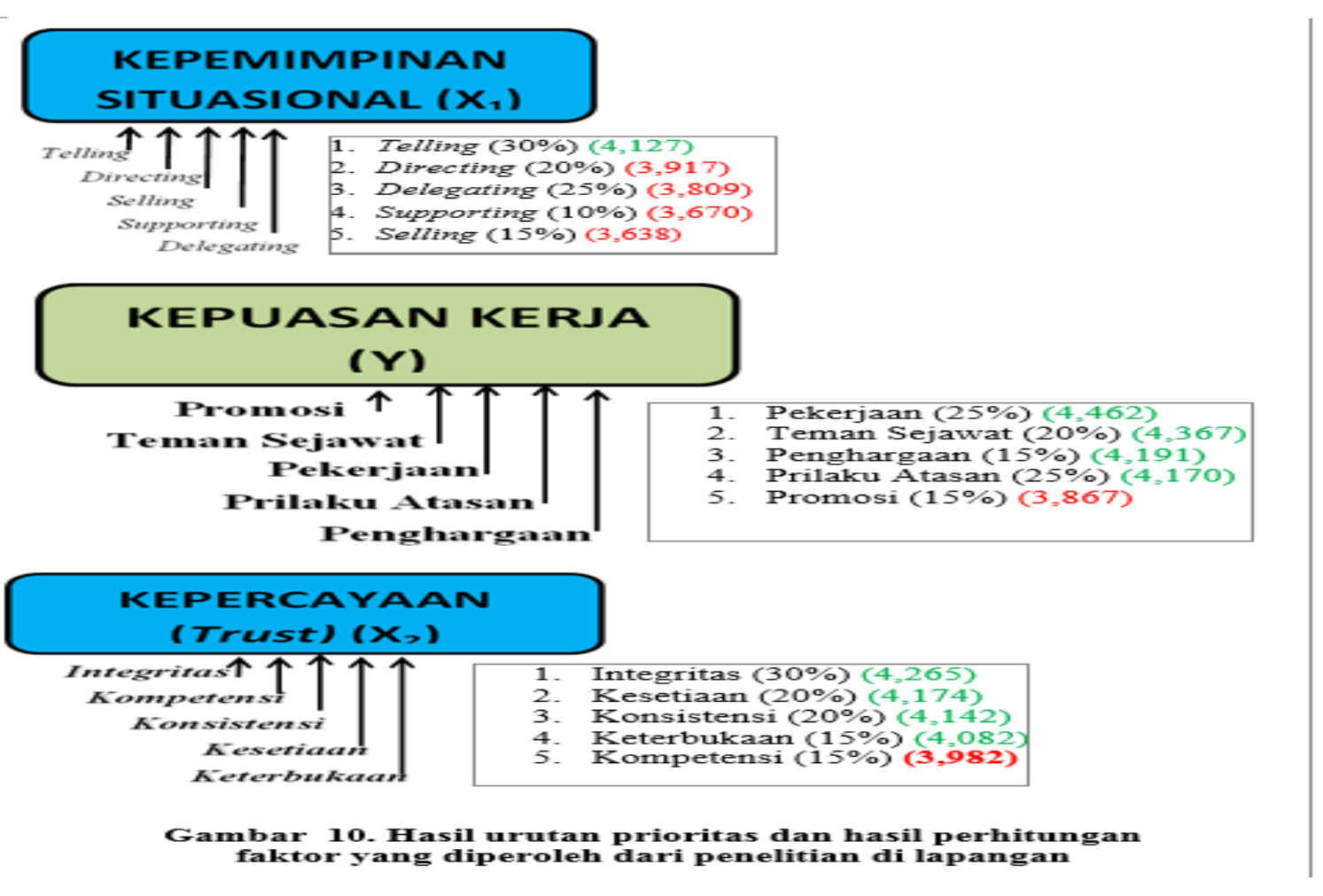




\section{DAFTAR PUSTAKA}

Barnes, James G.2003. Secrets Of Customer Relationship Management. Yogyakarta : Andi.

Calvin S. Hall \& Gardner Lidzey.2005. Teori-Teori Psiko Dinamik (Klinis).A. Supratiknya. Jakarta : Kanisius.

Freddy. Rangkuti, 2002, Measuring Customer Satisfactio. Teknik Mengukur Kepuasan Strategi Meningkatkan Kepuasan Pelanggan dan Analisis PL-JP. Jakarta : PT GramediaPustaka Tama.

Hendri Tanjung, Asep \& Isak. 2003.Manajemen Motivasi.Jakarta : PT. Gramedia Widia Sarana Indonesia.

John Wiley\&Sons Ltd. 2007. Trust, Complexity and Control Confidence in a Convergent World/Piotr Cofta,The Atrium, Southern Gate, Chichester, England : West Sussex PO19 8SQ.

Kreitner \& Kinicki. 2005. Perilaku Organisasi. buku 1. Jakarta : Salemba Empat

Malayu Hasibuan. 2012. Manajemen Sumber Daya Manusia. Jakarta :Cetakan ke Enam belas, Edisi Revisi, PT Bumi Aksara.

Maurer. I.2010.How to Build Trust in Inter-Organizational Projects. The Impact of Project Staffing and Project Rewards on the Format ion of Trust, Knowledge Acquisit ion and Product Innovation", International Journal of Project Management, Volume 28 : 629637.

Mulyo Sukoco.2000.Gaya Kepemimpinan dan Hubungannya Terhadap Semangat Kerja Dalam Upaya Peningkatan Kinerja pada Dinas P\&K Kabupaten Situbondo.

Nooteboom.B and Frederique.2003.The Trust Process in Organizations: Empirical Studies of The Determinants and The Process of Trust Development. England: Edward Elgar Publihsing Inc, Northampton.

Peppers, Don and Martha Rogers. 2004. Managing Customer Relationships: A Strategic Framework. New Jersey: John Wiley \& Sons, Inc.

Pinto, J.K., Slevin, D.P., and English, B.2009.Trust in Projects. An empirical Assessment of Owner/Contractor Relat ionships. International journal of Project Management. Volume 27: 638-648.

Robbbins dan Judge. 2007. Perilaku Organisasi. Jakarta : Salemba Empat.A.M.

Saunders Maks N.K et al.,2010.Cambridge Companions to Management.Organizational Trust. Eds. Cary Cooper CBE.

Schermerhorn et al.2010. Organizational Behavior. Edisi 11.Amerika : John Wiley \& Sons.

Sedarmayanti. 2011. Membangun dan Mengembangkan Kepemimpinan serta Meningkatkan Kinerja untuk Meraih Keberhasilan. PT. Refika Aditama.

Sheth, Jagdish N and Mittal, Banwari. 2004. Customer Behaviour Managerial Perspective. Second Edition. Singapore: Thomson.

Sopiah. 2008. Perilaku organisasional. Yogyakarta: CV. Andi Offset.

Suryadi. 2010. Kepemimpinan. Surabaya : Putra Media Nusantara.

Sutrisno, E. 2009. Manajemen sumber daya manusia. Jakarta: KencanaPrenada Media Group.

Syarifah Ida Farida, Muhammad Iqbal, \& Augustina Kurniasih.2016.Pengaruh Kepercayaan (trust) dan Komitmen Organisasi terhadap Motivasi dan Kepuasan Kerja.Jurnal Kependidikan.Volume 46, No. 1: 121-134.

Toman Sony Tambunan. 2015.Pemimpin dn Kepemimpinan. Jogyakarta: Graha Ilmu Triantoro Safaria.2004.Kepemimpinan.Yogyakarta : Graha Ilmu.

Weren, Thomas J.2006. The Quest for a General Theory of Leadership. University of Richmond. 